Między wykluczeniem a dobrobytem. Refleksja nad społeczną myśla encykliki „Centesimus annus” Jana Pawła II, red. B. Bąk,

R. Kantor, M. Kluz, J. Młyński, Kraków 2017, s. 181-211.

DOI: http://dx.doi.org/10.15633/9788374386289.09

\title{
Konstytucyjna zasada społecznej gospodarki rynkowej - w poszukiwaniu znamion polskiego modelu
}

\section{Uwagi wstępne}

W zależności od aksjologii przyjętej przez ustrojodawcę konstytucyjnego obowiązujący w danym państwie system prawny nadaje prymat określonym postawom ekonomicznym. Fundamentalne znaczenie ma w tym kontekście konstytucyjna regulacja ustroju gospodarczego. Naturalnie, ze szczególnej treści konstytucji ${ }^{1}$ wynika, że akt ten określa jedynie podstawowe instytucje ustroju państwowego oraz podstawowe zasady ich organizacji i funkcjonowania ${ }^{2}$. Oznacza to, że normatywna próba określenia funkcjonującego ustroju gospodarczego będzie w pierwszej kolejności opierała się na postanowieniach norm konstytucyjnych. Wynika to m.in. z faktu, że to konstytucja - jako akt

1 Szerzej na temat szczególnej treści Konstytucji m.in. L. Garlicki, Polskie prawo konstytucyjne. Zarys wykładu, Warszawa 2008, s. 34-36.

2 B. Banaszak, Prawo konstytucyjne, Warszawa 2008, s. 14. 
najwyższy rangą spośród wszystkich źródeł prawa krajowego - reguluje fundamentalne zasady ustrojowe, stwarza podstawowe warunki oraz kierunki i cele działania polityki gospodarczej, jak również organizację aparatu gospodarczego oraz kompetencje jego instytu$\mathrm{cji}^{3}$. Te ogólne normy konstytucyjne są następnie uszczegóławiane (wypełniane treścią) przez normy prawne niższe rangą, w szczególności ustawy.

Zarówno „ubóstwo”, jak i dobrobyt” są pojęciami wielowymiarowymi, występującymi w różnych dziedzinach życia społecznego, a w konsekwencji omawiane są przez przedstawicieli wielu dyscyplin naukowych. Cechą wspólną tych przedmiotowych kategorii jest to, iż w głównej mierze odnoszą się one do statusu materialnego i obrazują dwie przeciwstawne sytuacje ekonomiczne jednostki. Oba wyżej wymienione terminy mają też swoje umocowanie w dogmatyce prawa, przy czym obowiązujące przepisy znacznie częściej odwołują się do pojęcia ubóstwa ${ }^{4}$. Przywołać tutaj należy w szczególności regulacje znajdujące się w Ustawie z dnia 12 marca 2004 roku o pomocy społecznej, w których znajdują się określone przez ustawodawcę kryteria dochodowe pozwalające uznać daną osobę (rodzinę) za pozostającą w stanie ubóstwa, co w konsekwencji determinuje przyznanie określonych świadczeń społecznych ${ }^{5}$. Z kolei pojęcie dobrobytu pojawia się w polskim prawodawstwie sporadycznie ${ }^{6}$. Co istotne, jest ono traktowane jako pewnego rodzaju norma programowa - kieru-

3 T. Rabska, Prawo administracji stosunków gospodarczych, Warszawa-Poznań, 1973, s. 18-19; C. Kosikowski, Publiczne prawo gospodarcze Polski i Unii Europejskiej, Warszawa 2007, s. 55.

4 Por. m.in. art. 112 § 3 Ustawy z dnia 25.02.1964 Kodeks rodzinny i opiekuńczy (Dz. U. 2015 poz. 2082), art. 10 ustawy z dnia 29.07.2005 o przeciwdziałaniu narkomanii (Dz. U. 2016, poz. 224), art. 1 ustawy z 13.06.2003 o zatrudnieniu socjalnym (Dz. U. $2011 \mathrm{Nr} 43$, poz. 225).

5 Por. w szczególności art. 7-9 ustawy z dnia 12.03.2004 o pomocy społecznej (Dz. U. 2016, poz. 930).

6 Por. m.in. art. 4 ust. 1 ustawy z 24.07.2015 o Radzie Dialogu Społecznego i innych instytucjach dialogu społecznego (Dz. U. 2015, poz. 1240). 
nek działalności określonych podmiotów prawa. Nie ulega przy tym wątpliwości, że oba terminy są dużo częściej eksploatowane przez takie nauki społeczne jak ekonomia, socjologia, politologia.

$\mathrm{Z}$ punktu widzenia tematu niniejszego artykułu w sposób szczególny należy podkreślić odwołanie do dobrobytu i ubóstwa w naukach opisujących współczesne ideologie i doktryny polityczne. Ubóstwo jest w tym kontekście stanem niepożądanym, od którego się odchodzi i dąży do osiągnięcia stanu dobrobytu. Jest to w szczególności zauważalne w kontekście funkcjonowania aktualnie dominującej ideologii opartej na afirmacji indywidualizmu oraz wolności jednostki. Wydaje się zatem, że oba wymienione terminy znajdują się na przeciwstawnych biegunach osi opisującej możliwe statusy majątkowe. Spośród nich zjawiskiem dominującym (w sensie ilościowym) jest ubóstwo, podczas gdy dobrobyt jest perspektywą, która w (kapitalistycznych) liberalnych demokracjach staje się często samoistnym celem aktywności zarobkowej jednostki. W praktyce jednak status majątkowy zdecydowanej większość jednostek sytuuje się gdzieś pomiędzy tymi dwoma stanami granicznymi. Wydaje się, że w pewnym stopniu stan ten koresponduje $\mathrm{z}$ obowiązującą regulacją konstytucyjną odnoszącą się do obowiązującego w Polsce ładu gospodarczego. Konstytucja Rzeczypospolitej Polskiej z 1997 roku proponuje bowiem dość oryginalną koncepcję ustroju społeczno-gospodarczego. Zgodnie $\mathrm{z}$ art. 20 ustawy zasadniczej podstawę ustroju gospodarczego w Rzeczypospolitej Polskiej stanowi społeczna gospodarka rynkowa oparta na trzech filarach: 1) wolności działalności gospodarczej, 2) własności prywatnej oraz 3) solidarności, dialogu i współpracy partnerów społecznych ${ }^{7}$.

7 Por. art. 20 Konstytucji Rzeczypospolitej Polskiej z dnia 2.04.1997 roku (Dz. U. $\mathrm{Nr} 78$, poz. 483 ze zm.). 


\section{2. Źródła koncepcji społecznej gospodarki rynkowej}

Czym zatem wyróżnia się polskie ujęcie społecznej gospodarki rynkowej? Odpowiedź na tak postawione pytanie wymaga omówienia źródeł idei społecznej gospodarki rynkowej, ze szczególnym uwzględnieniem jej „społecznego” aspektu.

Koncepcja ta powstała w Niemczech jako propozycja stworzenia „trzeciej drogi” odrzucającej zarówno liberalizm gospodarczy leseferyzmu, jak i kolektywizm ${ }^{8}$. Jest ona związana głównie ze szkołą freiburską, tzw. ordoliberalizmem, to jest liberalizmem zakładającym, że konieczną cechą ustroju gospodarczego jest zagwarantowanie fundamentalnych, współzależnych wartości: ładu społecznego i gospodarczego ${ }^{9}$. W ramach tego porządku społeczno-gospodarczego realizowane mają być - równolegle, w sposób nierozdzielny - dwa podstawowe cele: swobodna inicjatywa oraz (oparte na sprawiedliwości społecznej i bezpieczeństwie socjalnym) społeczne zorganizowanie $^{10}$. Organizacja takiego społeczeństwa - dzięki kojarzeniu

8 Por. T. Włudyka, Model społecznej gospodarki rynkowej a transformacja ustrojowa polskiej gospodarki. Analiza prawnogospodarcza, Kraków 2002, s. 25. Na temat rozumienia społecznej gospodarki rynkowej w systemie niemieckim zob. D. Grosser, Społeczna gospodarka rynkowa - bezpieczeństwo socjalne. Doświadczenia Republiki Federalnej Niemiec - perspektywy zjednoczonych Niemiec, Warszawa 1993; E. Kundera, Ład społeczny i gospodarczy $w$ doktrynie ordoliberalizmu niemieckiego, w:Regulowana gospodarka rynkowa. Wybór materiałów do studiowania polityki gospodarczej, red. U. Kalina-Prasznic, Kraków 2007; Socjalna gospodarka rynkowa. Jak to robiq Niemcy, red. W. Sartorius, Warszawa 1992; M. J. Thieme, Społeczna gospodarka rynkowa, tłum. M. Trojan, Warszawa 1995; E. Dworak, W. Kasperkiewicz, Społeczna gospodarka rynkowa w RFN. Koncepcja, zasady działania, polityka gospodarcza i społeczna, Łódź 1995; P. Pysz, Społeczna gospodarka rynkowa. Ordoliberalna koncepcja polityki gospodarczej, Warszawa 2008 (Współczesna Ekonomia); H. Lampert, Porzq̨ek gospodarczy i społeczny Republiki Federalnej Niemiec, tłum. B. Spurgjasz, Warszawa 1993.

9 Ideę ordoiberalizmu omawia m.in. R. Skarżyński, Państwo i społeczna gospodarka rynkowa. Główne idee polityczne ordoliberalzimu, Warszawa 1994.

10 K. Strzyczkowski, Konstytucyjna zasada społecznej gospodarki rynkowej jako podstawa tworzenia i stosowania prawa, w: Zasady ustroju społecznego i gospodarczego 
przez władze publiczne interesów różnych grup społecznych - pozwala na osiągnięcie jednocześnie celów indywidualnych i ogólnospołecznych ${ }^{11}$. Teoria społecznej gospodarki rynkowej opiera się zatem na założeniu, że możliwa jest synteza wolności działania prywatnych podmiotów gospodarczych na rynku i realizacji celów sprawiedliwości społecznej ${ }^{12}$. Miało to nastąpić przez stabilną i spójną politykę gospodarczą państwa zmierzającą przede wszystkim do ochrony konkurencji oraz stymulowanie i korygowanie mechanizmów rynkowych, tak aby ustrój gospodarczy gwarantował swobodę działania rynku $^{13}$. Ordoliberałowie stali przy tym zdecydowanie na stanowisku, że element społeczny gospodarki rynkowej nie stanowi formy ograniczenia wolnego rynku. Gospodarka bowiem zawsze jest pewnym wycinkiem życia społecznego, a w związku z tym posiada społeczny wymiar. Oznacza to, że ustroju gospodarczego nie można oddzielić od ustroju społecznego, zaś gospodarka nie może być uregulowana bez odniesień społecznych. Rynek, wedle tej szkoły, jest zatem instytucją społeczną istniejącą w otoczeniu społeczno-kulturowym oraz otoczeniu instytucjonalno-prawnym, które „porządkują” działanie mechanizmów wolnorynkowych ${ }^{14}$. Dlatego właśnie w określeniu liberałów ze szkoły freiburskiej pojawił się przedrostek „ordo-”. W przyjętej koncepcji gospodarka rynkowa i jej społeczny komponent są względem siebie komplementarne, warunkują się nawzajem ${ }^{15}$.

w procesie stosowania Konstytucji, red. C. Kosikowski, Warszawa 2005, s. 11 (Podstawowe Problemy Stosowania Konstytucji Rzeczypospolitej Polskiej).

11 J. Ciapała, Społeczna gospodarka rynkowa, w: Konstytucja Rzeczypospolitej Polskiej. Komentarz encyklopedyczny, red. W. Skrzydło, S. Grabowska, R. Grabowski, Warszawa 2009, s. 557.

12 Społeczna gospodarka rynkowa. Idee i możliwości praktycznego wykorzystania w Polsce, red. E. Mączyńska, P. Pysz, Warszawa 2003, s. 12 (Ekonomia i Świat Współczesny).

13 J. Ciapała, Konstytucyjna wolność działalności gospodarczej w Rzeczypospolitej Polskiej, Szczecin 2009, s. 71.

14 P. Czarnek, Zasada społecznej gospodarki rynkowej, w: Zasady ustroju III Rzeczypospolitej Polskiej, red. D. Dudek, Warszawa 2009, s. 281.

15 K. Strzyczkowski, Konstytucyjna zasada..., dz. cyt., s. 12. 
W związku z tym za podstawowy cel społecznej gospodarki rynkowej uważane jest zapewnienie stałego wzrostu gospodarczego i jego stabilizacja ${ }^{16}$. Wszelkie społeczne cele gospodarki są uzależnione od jej efektów ekonomicznych, tylko wzrost gospodarczy jest bowiem w stanie umożliwić realizację „społecznego" aspektu gospodarki rynkowej. Z drugiej strony natomiast wszelkie środki polityki społecznej podważające zasady gospodarki rynkowej są uzasadnione wyłącznie zawodnością samych mechanizmów rynkowych. Środki polityki społecznej stosowane bezzasadnie prowadzą do obniżenia efektywności gospodarki, a w konsekwencji do negatywnych skutków społecznych ${ }^{17}$.

Przez społeczną gospodarkę rynkową rozumiano zatem ustrój gospodarczy, który z jednej strony (jako punkt wyjścia) akceptuje zasady liberalizmu gospodarczego i wolnego rynku, z drugiej jednak nadaje szczególną rangę celom społecznym powiązanym z procesem gospodarczym i dla ich osiągnięcia dopuszcza interwencjonizm państwowy $^{18}$. Oznacza to, że w sferze relacji pomiędzy tym, co socjalne (społeczne), a tym, co rynkowe w społecznej gospodarce rynkowej bez wątpienia przewaga przyznana została rynkowi ${ }^{19}$. Jako koncepcja polityczno-gospodarcza społeczna gospodarka rynkowa jest zatem ukierunkowana na syntezę wolności zabezpieczonej przez państwo prawa ${ }^{20}$. Właśnie dlatego, z powodu wbudowanej w ustrój gospodarki rynkowej potencjalnej sprzeczności pomiędzy swobodą działania gospodarczego a utrzymaniem więzi społecznej, system społecznej

16 K. Grimm, Koncepcja, historia i praktyka socjalnej gospodarki rynkowej, w: Socjalna gospodarka rynkowa..., dz. cyt., s. 16-17.

17 K. Strzyczkowski, Konstytucyjna zasada..., dz. cyt., s. 12-13.

18 Na temat interwencjonizmu państwowego por. m.in. T. Ławicki, Organizacja i formy prawne interwencjonizmu państwowego w okresie przechodzenia do gospodarki rynkowej, w: Państwo i prawo w gospodarce rynkowej. Problemy dostosowawcze, red. C. Kosikowski, Łódź 1993, s. 31-50.

19 Z. A. Maciąg, Kształtowanie zasad państwa demokratycznego prawnego socjalnego w Niemczech (do 1949 r.), Białystok 1998, s. 224-228.

20 H. Lampert, Porzqdek gospodarczy..., dz. cyt., s. 63. 
gospodarki rynkowej wskazywany jest jako najtrudniejszy do ukształtowania i utrzymania rodzaj porządku gospodarczego ${ }^{21}$.

W związku z tym aby zrealizować ideę społecznej gospodarki rynkowej, należy z jednej strony tworzyć mechanizmy zabezpieczające wolność gospodarczą, wolną konkurencję i zapobiegające powstawaniu monopoli, a z drugiej strony ukierunkować gospodarkę na zwiększający się etatyzm oraz interwencjonizm państwowy. Kierunek ten nawiązuje wyraźnie do koncepcji państwa socjalnego, a nawet do szerszej idei państwa dobrobytu ${ }^{22}$. Konsekwencją takiego rozumienia społecznej gospodarki rynkowej jest zobowiązanie państwa do podejmowania działań łagodzących społeczne skutki funkcjonowania praw rynku, a więc ustanowienie pewnych interwencjonistycznych regulatorów procesów gospodarczych w celu zapewnienia „równowagi społecznej”. Realizacji „równowagi społecznej” służy zwłaszcza polityka państwa, zakładająca konieczność dokonywania korekt dochodu narodowego drogą podatków, subwencji, świadczeń socjalnych

21 K. Grimm, Koncepcja..., dz. cyt., s. 20.

22 Tak m.in. L. Garlicki, Polskie prawo konstytucyjne..., dz. cyt., s. 78; Prawo konstytucyjne Rzeczypospolitej Polskiej, red. P. Sarnecki, Warszawa 2002, s. 43; Polskie prawo konstytucyjne, red. D. Górecki, Warszawa 2009, s. 73; por. również Informacja o istotnych problemach wynikajacych z działalności i orzecznictwa Trybunału Konstytucyjnego w 2001 roku, Warszawa 2002, s. 81. Pojęcie „państwa socjalnego" ma swoje źródła w niemieckim prawodawstwie konstytucyjnym i oznacza, że wszystkie organy zobowiązane są tak wypełniać swoje funkcje, aby uwzględniać prawa socjalne jednostki i zapewniać ich wykonanie. Działalność państwa w tym zakresie nie ogranicza się przy tym jedynie do ustanowienia gwarancji formalnych, lecz obejmuje swoim zakresem także działania o charakterze prawnym, ekonomicznym, politycznym i kulturalnym. Do najważniejszych zadań organów państwowych należy: zapewnienie każdemu podległemu ich władzy minimum egzystencji godnej człowieka, zapewnienie równości socjalnej, co implikuje przyznanie niekiedy grupom słabszym socjalnie dodatkowych uprawnień, a także udzielanie pomocy socjalnej w stanach koniecznych - tak, aby utrzymać na odpowiednim poziomie standard życia jednostki. Por. B. Banaszak, System konstytucyjny Niemiec, Warszawa 2005, s. 31-32 (Systemy Konstytucyjne Państw Świata). Na temat idei państwa dobrobytu zob. S. Zawadzki, „Państwo dobrobytu" - doktryna i praktyka, Warszawa 1970. 
i innych tego typu środków ${ }^{23}$. Tak rozumiane państwo socjalne jest również wyposażone $\mathrm{w}$ wiele instrumentów oraz narzędzi polityki socjalnej. Bez wątpienia rzutuje to również na sposób postrzegania zasady sprawiedliwości społecznej określającej w pierwszej kolejności zasady redystrybucji dóbr ${ }^{24}$.

\section{Społeczna gospodarka rynkowa na gruncie polskiego porządku ustrojowego}

Polska koncepcja społecznej gospodarki rynkowej ma swoistą treść normatywną nawiązującą do pewnych elementów funkcjonujących we wspomnianym wyżej modelu niemieckim, a w związku z tym postanowienia art. 20 Konstytucji RP należy interpretować zgodnie $\mathrm{z}$ ustaleniami poczynionymi w tym zakresie przez tamtejszą doktrynę i praktykę ${ }^{25}$. Jednakże okazuje się, że proste przeniesienie tej koncepcji na grunt polski jest niezwykle trudne ${ }^{26}$. Ponadto względy historyczne powodują, że polski model korzysta z innych rozwiązań instytucjonalnych. Wydaje się, że występowanie tych różnic można uznać za uzasadnione przynajmniej z następujących względów:

23 J. Kuciński, Konstytucyjny ustrój państwowy Rzeczypospolitej Polskiej, Warszawa 2003, s. 84.

24 Na ideę sprawiedliwości dystrybutywnej powołuje się w swoim orzecznictwie również polski Trybunał Konstytucyjny (por. m.in. wyrok Trybunału Konstytucyjnego z dnia 22.08.1990, sygn. K 7/90; wyrok Trybunału Konstytucyjnego z dnia 9.03.1987, sygn. U 7/87; wyrok Trybunału Konstytucyjnego z dnia 11.02.1992, sygn. K 14/91; wyrok Trybunału Konstytucyjnego z dnia 12.12.1994, sygn. K 3/94; wyrok Trybunału Konstytucyjnego z dnia 3.09.1996, sygn. K 10/96; wyrok Trybunału Konstytucyjnego z dnia 20.11.1996, sygn. K 27/95, wyrok Trybunału Konstytucyjnego z dnia 24.04.2006, sygn. P 9/05). Więcej na ten temat również A. Domańska, Zasady sprawiedliwości społecznej we współczesnym polskim prawie konstytucyjnym, Łódź 2001, s. 104-129.

25 Por. T. Włudyka, Model społecznej gospodarki..., dz. cyt., s. 82.

26 T. T. Kaczmarek, P. Pysz, Ludwig Erhard i społeczna gospodarka rynkowa, Warszawa 2004, s. 151. 
1) mającyego swoje źródła w czasach komunizmu daleko idącego zaangażowania państwa w procesy gospodarcze (etatyzmu), 2) znaczącej roli partnerów społecznych (związków zawodowych) w procesach transformacji ustrojowej (obejmujących również sferę ustroju gospodarczego) oraz 3) długotrwałego usytuowania obywateli w opozycji do państwa, co skutkuje niskim poziomem rozwoju społeczeństwa obywatelskiego w Polsce.

Wskazać również należy, że prace Komisji Konstytucyjnej Zgromadzenia Narodowego nad aktualnym brzmieniem art. 20 Konstytucji wskazują, iż proste przełożenie niemieckiego rozumienia społecznej gospodarki rynkowej na grunt polski nie było intencją ustrojodawcy. Inaczej widział to co prawda ekspert Komisji Michał Zieliński, który podnosił, że pojęcie społecznej gospodarki rynkowej jest kalką językową z języka niemieckiego i oznacza prospołeczną gospodarkę rynkową, tj. taką, która uwzględnia wszystkie elementy istnienia społeczeństwa ${ }^{27}$. Autor aktualnego brzmienia art. 20 Marek Borowski argumentował natomiast, że tak zdefiniowane podstawy - mającej swój rodowód w doktrynie niemieckiej - koncepcji społecznej gospodarki rynkowej nie muszą być wiernie recypowane do polskiego systemu, gdyż w Polsce społeczną gospodarkę rynkową przyjęło się rozumieć trochę inaczej ${ }^{28}$.

Nie tylko względy historyczne, lecz także literalne brzmienie art. 20 wychodzi naprzeciw postulatowi poszukiwania nieco odmiennego rozumienia koncepcji społecznej gospodarki rynkowej na gruncie obowiązującej Konstytucji RP. Jak bowiem wskazano wyżej, zgodnie z przedmiotowym przepisem społeczną gospodarkę rynkową tworzą trzy filary: 1) wolność działalności gospodarczej, 2) własność prywatna oraz 3) solidarność, dialog i współpraca partnerów

27 Por. Biuletyn Komisji Konstytucyjnej Zgromadzenia Narodowego XLIV, Warszawa 1997, s. 87-88.

28 Por. Biuletyn Komisji Konstytucyjnej Zgromadzenia Narodowego XLIV, dz.cyt., s. 34-35. 
społecznych. Zdaniem Trybunału Konstytucyjnego, ustrojodawca traktuje wymienione $\mathrm{w}$ art. 20 wartości kompleksowo i komplementarnie. Kompleksowo, ponieważ ujmuje je jako całość i żadnej $\mathrm{z}$ nich nie wyróżnia. Komplementarnie natomiast, ponieważ wartości te powiązane są ze sobą w ten sposób, że mogą się i wzajemnie wspierać, i ograniczać ${ }^{29}$. Ograniczeniom podlega zatem zarówno wolność działalności gospodarczej, jak i własność prywatna oraz solidarność, dialog i współpraca partnerów społecznych. Gdyby było inaczej, nie można byłoby mówić o tym, że gospodarka rynkowa ma wymiar społeczny ${ }^{30}$.

Z powyższego wynika, że społeczną gospodarkę rynkową kształtują z jednej strony elementy tradycyjnej gospodarki rynkowej (wolność gospodarcza, własność prywatna), a z drugiej określone cechy ładu społecznego (solidarność, dialog i współpraca partnerów społecznych).

Nie ulega przy tym wątpliwości, że dwie pierwsze spośród wyżej wymienionych wartości znajdą swoje umocowanie w ordoliberalnym rozumieniu idei społecznej gospodarki rynkowej.

Wolność działalności gospodarczej jest postrzegana jako konstytucyjna zasada ustrojowa oraz jako prawo podmiotowe o charakterze negatywnym. Oba wymienione ujęcia wolności działalności gospodarczej są ze sobą ściśle powiązane, co wynika z literalnej wykładni art. 20 i art. 22 Konstytucji oraz integracyjnej funkcji ustawy zasadniczej. Wolność gospodarcza jako zasada ustrojowa w zasadniczej mierze ukształtowana jest przez zasadę społecznej gospodarki rynkowej, zaś jej granice w największym zakresie kształtowane są przez „,solidarność, dialog i współpracę partnerów społecznych". Ustrojowa zasada wolności gospodarczej jest ukierunkowana na realizację wspomnia-

29 Wyrok Trybunału Konstytucyjnego z dnia 30.01.2001, sygn. K 17/00.

30 C. Kosikowski, Wolność działalności gospodarczej i jej ograniczenia w praktyce stosowania Konstytucji RP, w: Zasady ustroju społecznego i gospodarczego w procesie stosowania Konstytucji, dz. cyt., s. 45. 
nego w art. 1 „dobra wspólnego wszystkich obywateli”, co w kontekście ustroju gospodarczego dotyczy zarówno interesu przedsiębiorców, jak i innych partnerów społecznych (w szczególności pracowników oraz konsumentów). Ponadto omawiana zasada ustrojowa stanowi wskazówkę dla organów władzy publicznej w procesie stanowienia i stosowania prawa zapewniającego ochronę swobody gospodarowania. W konsekwencji istotą konstytucyjnej zasady ustrojowej jest ochrona wolności działalności gospodarczej - prawa podmiotowego. W tym sensie zasada ta pełni funkcję pomocniczą i dopełniającą treść samej wolności - prawa podmiotowego o charakterze negatywnym.

Z kolei wolność działalności gospodarczej jako prawo podmiotowe o charakterze negatywnym ma swoje aksjologiczne i normatywne źródło w zasadzie ochrony godności człowieka. Prawo to kształtowane jest przez jednostkę w sposób dowolny, zaś państwu zabrania się $\mathrm{w}$ to prawo nieproporcjonalnie ingerować. Wolność ta ma charakter specyficzny, gdyż jest proklamowana w rozdziale I Konstytucji, brak jest natomiast jakichkolwiek wzmianek na jej temat w poświęconym prawom i wolnościom jednostki rozdziale II. Zakres jej oddziaływania może być poszerzany głównie na podstawie sentencji „in dubio pro libertate” 31 .

Wyrażone w art. 20 Konstytucji sprzężenie wolności działalności gospodarczej z własnością prywatną świadczy o tym, że szczególną konstytucyjną ochroną objęta jest działalność gospodarcza, dla której materialną podstawą jest szeroko pojęta własność prywatna, nie jest natomiast nią objęta działalność prowadzona przez państwo i różne instytucje publiczne z wykorzystaniem majątku Skarbu Państwa, innych państwowych osób prawnych lub mienia należącego

31 Szersze omówienie konstytucyjnego ujęcia wolności działalności gospodarczej dostępne m.in. w następujących publikacjach: J. Ciapała, Konstytucyjna wolność..., dz. cyt., A. Ogonowski, Konstytucyjna wolność działalności gospodarczej w orzecznictwie Trybunału Konstytucyjnego, „Przegląd Prawa Konstytucyjnego" 2011 nr 9, s. 213-235. 
do jednostek samorządu terytorialnego. Trybunał Konstytucyjny zwraca przy tym uwagę, że sektor publiczny nie może być traktowany w sposób uprzywilejowany w stosunku do podmiotów prywatnych, natomiast - $z$ uwagi na jego inne funkcje - mogą być tu wprowadzane ograniczenia i regulacje, które z punktu widzenia konkurencyjności mogą być traktowane jako dodatkowe utrudnienie i obciążenie. Warto przy tym dodać, że z punktu widzenia art. 20 Konstytucji (jako konstytucyjnej zasady ustroju gospodarczego) podmioty publiczne nie tylko mają działać w ramach „czystych” zasad rynkowych (prawa popytu i podaży), lecz także powinny wprowadzać w gospodarce elementy społeczne, które stanowią uzupełnienie i podstawę do pewnych korekt zasad rynkowych ${ }^{32}$.

Z powyższego wynika zatem, że podstawowe miejsce w systemie gospodarki ma przypadać własności prywatnej, co należy odczytywać jako zalecenie dla ustawodawcy, by dążył do rozszerzania i umacniania właśnie tej formy własności ${ }^{33}$. Pamiętać jednak należy, że przyjęty w regulacjach konstytucyjnych model własności stanowi wyraz określonej przez państwo koncepcji organizacji społeczeństwa i gospodarki. Prawo bowiem kształtuje stosunki własnościowe stosownie do założeń ideowych i innych wymogów, także politycznych ${ }^{34}$. W konsekwencji podkreśla się, że pojęcie własności podlega zmianom, które zachodzą w rzeczywistości społecznej i przynoszą ze sobą modyfikacje funkcji własności w kierunku zwiększenia zakresu jej społecznych obowiązków. Własność jest więc realizowana indywidualnie w swojej zasadzie, zaś socjalnie w zakresie korzystania $\mathrm{z}$ niej ${ }^{35}$. Mowa tutaj o społecznej funkcji prawa własności, które

32 Wyrok Trybunału Konstytucyjnego z 7.05.2001, sygn. K 19/00, OTK 2001/4/82.

33 Por. S. Jarosz-Żukowska, Konstytucyjna zasada ochrony własności, Kraków 2003, s. 109-111.

34 C. Kosikowski, Zasada ochrony własności, w: Zasady podstawowe polskiej konstytucji, red. W. Sokolewicz, Warszawa 1998, s. 228.

35 Por. S. Jarosz-Żukowska, Konstytucyjna zasada ochrony własności, dz. cyt., s. 162nn. 
ściśle koresponduje z odwołaniem do solidarności, dialogu i współpracy partnerów społecznych.

Odwołanie do tej idei stanowi swoistą wizytówkę konstytucyjnej regulacji ustroju gospodarczego w Polsce. O ile bowiem odwołanie do solidarności znajdzie jeszcze swoje formalne źródło w niemieckiej koncepcji państwa socjalnego, o tyle w dogmatyce prawa konstytucyjnego trudno odnaleźć zbyt wiele odwołań do „dialogu i współpracy partnerów społecznych”. To właśnie ten fragment art. 20 Konstytucji RP będzie w sposób szczególny wyróżniać polskie ujęcie społecznej gospodarki rynkowej.

Powyższe rozumowanie skłania również do powściągliwości w sferze utożsamiania polskiej koncepcji społecznej gospodarki rynkowej z ideą państwa socjalnego, w którym dominuje interwencjonizm państwowy oraz interpretowana jednokierunkowo (jako sposób redystrybucji dóbr) idea sprawiedliwości społecznej. Co więcej, w literaturze podnosi się, że państwo socjalne to zniekształcona koncepcja ordoliberalnej społecznej gospodarki rynkowej, gdzie polityka społeczna państwa w głównej mierze - w imię prymatu polityki socjalnej nad gospodarką - stanowi obciążenie dla gospodarki przez rosnący pakiet świadczeń socjalnych, co w konsekwencji prowadzi do kryzysu państwa socjalnego ${ }^{36}$.

W związku z tym w ramach alternatywnego kierunku myślenia o społecznym aspekcie gospodarki rynkowej na pierwszy plan wysunąć należy aktywność państwa w zakresie kształtowania zorganizowanego społeczeństwa obywatelskiego, opierającego się na solidarności, pluralizmie i dialogu społecznym. W dekodowaniu pojęcia społecznej gospodarki rynkowej istotne znaczenie ma bowiem fakt, że określenie solidarności, dialogu i współpracy partnerów społecznych jako jednej z podstaw ustroju gospodarczego RP oznacza, iż rola państwa - przynajmniej w sferze gospodarki - jest ograniczona. 
Analiza art. 20 Konstytucji RP prowadzi bowiem do wniosku, że społeczny charakter gospodarki rynkowej mają zapewnić przede wszystkim dialog i współpraca partnerów społecznych, a nie interwencjonizm państwa ${ }^{37}$.

Z proklamowanej przez art. 20 zasady solidarności nie wynika jednak, co należy wyraźnie podkreślić, że interwencjonizm państwowy nie jest w polskim porządku ustrojowym zupełnie wykluczony. Wydaje się, że w pewnym stopniu dopuszczalne jest wystąpienie niezbędnej ingerencji państwa w kształtowanie ładu gospodarczego w celu zapewnienia zrównoważonego wzrostu gospodarczego, ograniczenia bezrobocia, ochrony konkurencji, wyrównywania dysproporcji gospodarczych itp. ${ }^{38}$. Co więcej, można wyobrazić sobie tego rodzaju sytuacje, w których interwencjonizm państwowy będzie konieczny. Norma art. 20 Konstytucji RP nie rozstrzyga bowiem o dopuszczalności oddziaływania przez państwo na rynek, a zwłaszcza nie przesądza o zakresie interwencjonizmu państwowego, gdyż w tej kwestii decydujące znaczenie mają art. 146 Konstytucji RP, który przyznaje Radzie Ministrów kompetencję do decydowania o treści polityki gospodarczej, oraz art. 227, który określa zadania i kompetencje Narodowego Banku Polskiego.

Uzasadnione wydaje się jednak stanowisko, że organizacja syste$\mathrm{mu}$ interwencjonizmu państwowego $\mathrm{w}$ sferze gospodarczej powinna umożliwiać zrzeszeniom obywateli udział w realizacji niektórych funkcji państwa w odniesieniu do gospodarki ${ }^{39}$. Podejście takie pozwala bowiem wskazać te elementy interwencjonizmu państwowego, które wpisują się w ideę solidarności, dialogu i współpracy partnerów

37 W. Sanetra, Konstytucyjne prawo do rokowań, „Praca i Zabezpieczenie Społeczne” $1998 \mathrm{nr} 12$, s. 4.

38 Tak. m.in. C. Kosikowski, Polskie publiczne prawo gospodarcze, Warszawa 2002, s. 79-82; Z. Witkowski, Wybrane zasady ustroju Rzeczypospolitej, w: Prawo konstytucyjne, red. Z. Witkowski, Toruń 2009, s. 82-83; K. Strzyczkowski, Konstytucyjna zasada..., dz. cyt., s. 10-18.

39 T. Ławicki, Organizacja..., dz. cyt., s. 43. 
społecznych. Zaznacza się również w tym kontekście, że model interwencjonizmu państwowego przyjęty $\mathrm{w}$ rozwiązaniach polskich zakłada udział związków zawodowych w zarządzaniu i kierowaniu działalnością gospodarczą, przy czym udział ten jest ograniczony do określonych funkcji, form oraz szczebli ${ }^{40}$. Postuluje się również budowę społecznej gospodarki rynkowej w oparciu o proces szeroko rozumianego procesu korporatyzacji (usamorządowienia) gospodarki i społeczeństwa ${ }^{41}$.

Reasumując, obowiązywanie zasady społecznej gospodarki rynkowej wynika z uzasadnienia, które uwzględnia nie tylko racjonalność gospodarczą, lecz także wartości ogólnoludzkie (solidaryzm, godność człowieka, sprawiedliwość) ${ }^{42}$. W efekcie w społecznej gospodarce rynkowej podkreśla się potrzebę harmonii i współdziałania różnych sfer funkcjonowania gospodarki ${ }^{43}$. Jedną $\mathrm{z}$ takich form współdziałania (prowadzącym do harmonii stosunków gospodarczych) może być dialog podmiotów będących stronami tych stosunków - partnerów społecznych. Istotą społecznej gospodarki rynkowej jest w związku z tym paralelność, a nie alternatywność celów społecznych i gospodarczych. Głównym czynnikiem uspołeczniania gospodarki, co wynika $\mathrm{z}$ odwołania do konstytucyjnie umocowanego „dialogu i współpracy partnerów społecznych” (wspieranego przez zasadę pomocniczości wyartykułowaną w preambule do Konstytucji RP), jest nie tyle państwo, ile niżej zorganizowane zrzeszenia i związki oraz wszelkie poczynania zbiorowe o określonej autonomii działania. Podstawowym zadaniem państwa jest natomiast

40 T. Ławicki, Organizacja..., dz. cyt., s. 44.

41 T. Przeciszewski, Społeczna gospodarka rynkowa (SGR). Propozycje w zakresie rozwiqzań systemowo-organizacyjnych, składajacych się na jej specyfikację jako tzw. trzeciej drogi, w: Społeczna gospodarka rynkowa w Polsce. Model a rzeczywistość, red. S. Partycki, Lublin 2000, s. 417-418.

42 K. Strzyczkowski, Konstytucyjna zasada..., dz. cyt., s. 15.

43 Por. Konstytucje Rzeczypospolitej oraz komentarz do Konstytucji RP z 1997 roku, red. J. Boć, Wrocław 1998, s. 51. 
stworzenie warunków do realizacji społecznych celów gospodarki rynkowej ${ }^{44}$. Jest to tym bardziej istotne, że idea społecznej gospodarki rynkowej jest punktem wyjścia konstruowania nie tyle szczegółowych norm prawnych, ile raczej zasad - norm (zasad opisowych, metaklauzul), które są dopiero tworzywem do budowy norm konstytucyjnych sensu stricto. Jednocześnie $\mathrm{z}$ art. 20 można wydobywać pewne treści normatywne. W tym sensie przepis ten wyznacza pewne ramy działalności ustawodawczej oraz zawiera dyrektywy interpretacji innych, bardziej szczegółowych norm konstytucyjnych ${ }^{45}$.

\section{Solidarność, dialog i współpraca partnerów społecznych jako społeczny komponent polskiego ustroju gospodarczego}

Z dotychczasowych rozważań wynika między innymi, że konstytucyjna koncepcja społecznej gospodarki rynkowej oznacza obowiązek podjęcia przez władze publiczne działań o charakterze regulacyjno-interwencyjnym ${ }^{46}$, orientujących gospodarkę na cele społeczne (sprawiedliwość społeczną) w sposób podnoszący efektywność gospodarki rynkowej. Społeczny aspekt kształtowania ustroju gospodarczego opierać się winien przede wszystkim na „solidarności, dialogu i współpracy partnerów społecznych”. Kluczowe wydaje się zatem dekodowanie tego pojęcia oraz wskazanie praktycznych mechanizmów oraz instytucji urzeczywistniających zacytowany fragment art. 20 Konstytucji RP.

Jak podnosi Trybunał Konstytucyjny:

44 K. Strzyczkowski, Konstytucyjna zasada..., dz. cyt., s. 16-18.

45 L. Garlicki, Komentarz do art. 20, w: Konstytucja Rzeczypospolitej Polskiej. Komentarz, t. IV, red. L. Garlicki, Warszawa 2005, s. 16-17.

46 Mowa tutaj o pierwszeństwie regulacji ładu gospodarczego przez państwo nad interwencjonizmem państwowym. 
społeczna gospodarka rynkowa, o której mowa w art. 20 konstytucji, wspiera się na solidarności, dialogu i współpracy partnerów społecznych, co zakłada koncepcję równowagi interesów uczestników rynku i zarazem poszanowania ich autonomii, tworząc konstytucyjną gwarancję negocjacyjnego sposobu rozstrzygania spraw spornych, umożliwiającą przezwyciężanie napięć i konfliktów w procesie gospodarowania. Źródeł powyższych wartości upatrywać należy w filozofii społecznej, znanej pod nazwą solidaryzmu społecznego. Zgodnie z poglądami jego przedstawicieli życie społeczne opiera się na współzależności i współodpowiedzialności wszystkich jego uczestników. Solidaryzm głosi zgodność i wspólnotę interesów wszystkich jednostek i grup społecznych w obrębie danej społeczności, a także obowiązek partycypowania w obciążeniach na rzecz społeczeństwa. Zakłada wzajemne zrozumienie między jednostkami, grupami społecznymi i państwem ${ }^{47}$.

Z zacytowanego fragmentu wynika zatem, że to solidarność jest wartością, na którą winny być ukierunkowane dialog i współpraca partnerów społecznych.

Założenie takie potwierdza również stwierdzenie, iż solidarność, dialog i współpraca partnerów społecznych stanowią określenia dla pewnych wartości, w oparciu o które powinna funkcjonować społeczna gospodarka rynkowa, jak również określają one pewne ramy procesu podejmowania decyzji społecznych i gospodarczych, zarówno $\mathrm{w}$ aspekcie materialnym, jak i proceduralnym. W wymiarze materialnym pojęcia te zakładają nakaz podejmowania decyzji społeczno-gospodarczych na zasadzie kompromisu, pozwalającego na zrównoważenie przeciwstawnych interesów poszczególnych partnerów społecznych. Tym samym każdy z partnerów musi być gotowy do uznania i zaakceptowania potrzeb i interesów pozostałych stron 
dialogu - jego treścią ma być sformułowanie rozstrzygnięcia równomiernie rozkładającego ustępstwa i korzyści ${ }^{48}$. Aspekt materialny omawianego fragmentu art. 20 reprezentowany jest zatem przez odwołanie do solidarności. W wymiarze proceduralnym omawiana wytyczna realizowana jest przez „dialog i współpracę”. Pojęcia te nakazują stworzenie negocjacyjnego sposobu rozstrzygania spraw spornych, czego doprecyzowanie stanowią między innymi postanowienia art. 59 ust. 2 i 3 Konstytucji ${ }^{49}$. System negocjacyjny rozumiany jest jako umożliwienie partnerom społecznym uczestnictwa w kształtowaniu zasad funkcjonowania polskiej społecznej gospodarki rynkowej oraz w opracowywaniu i podejmowaniu dotyczących ich decyzji. W związku z tym obowiązkiem ustawodawcy jest stworzenie niezbędnej infrastruktury prawnej i instytucjonalnej, a także zagwarantowanie, że w każdej istotnej sprawie spornej będzie istniała procedura dialogu pozwalająca na poszukiwanie rozwiązania ${ }^{50}$. Jak zauważył Trybunał Konstytucyjny, przy jej kształtowaniu konieczne jest zapewnienie wszystkim partnerom społecznym możliwie równorzędnej sytuacji negocjacyjnej ${ }^{51}$. Równie istotne jest to, aby powstały system negocjacyjny nie skutkował niemożnością podjęcia jakiejkolwiek decyzji ${ }^{52}$.

Powyższe rozważania potwierdza także stanowisko innych przedstawicieli doktryny: Cezarego Banasińskiego, Anny Domańskiej oraz Jana Bocia ${ }^{53}$. Zdaniem J. Bocia odwołanie do solidarności nawiązuje do nauki społecznej Kościoła katolickiego i jest szczególnie bliskie

48 L. Garlicki, Komentarz do art. 20, dz. cyt., s. 14.

49 J. Kuciński, Konstytucyjny ustrój państwowy..., dz. cyt., s. 86-87.

50 L. Garlicki, Komentarz do art. 20, dz. cyt., s. 14.

51 Wyrok Trybunału Konstytucyjnego z dnia 18.11.2002, sygn. K 37/01.

52 Por. postanowienie Trybunału Konstytucyjnego z dnia 1.09.2002 roku, sygn. K 17/02.

53 Por. wyrok Trybunału Konstytucyjnego z dnia 30.01.2001, sygn. K 17/00; C. Banasiński, Konstytucyjne podstawy porzadku prawnego w gospodarce, w: Konstytucja. Trybunał Konstytucyjny: zbiór studiów, red. C. Banasiński, J. Oniszczuk, Warszawa 1998, s. 27-28; A. Domańska, Zasady sprawiedliwości społecznej..., dz. cyt., s. 127-135. 
społeczeństwu polskiemu. Podobnie jak A. Domańska stwierdza on również, że solidarności nie da się narzucić nakazem prawnym; nie da się też zobowiązać partnerów społecznych do tego, aby kierowali się interesem ogólnym, a nie partykularnym. Dialog i współpraca natomiast sprzyjać powinny harmonizowaniu stosunków ekonomicznych i społecznych, łagodzeniu dysproporcji, napięć i konfliktów. W związku z tym wspomniana formuła wyraża dążenie do wymiany informacji i poglądów, poszukiwania płaszczyzn porozumienia i kompromisu. Powinna ona zapobiegać konfliktom, stratom ekonomicznym podmiotów gospodarczych i grup pracowniczych oraz powstrzymywać zakłócenia w funkcjonowaniu gospodarki i sfery usług społecznych. Zdaniem J. Bocia metody koncyliacji, dialogu i poszukiwania konsensusu odgrywają szczególną rolę w regulacji sytuacji ekonomicznej różnych sektorów gospodarki, a także w polityce płac, podatków i świadczeń socjalnych ${ }^{54}$.

Wydaje się zatem, że w ramach omawianego pojęcia wyróżnić można dwa (ściśle powiązane, współzależne i uzupełniające się) elementy, tj. 1) materialną „solidarność” oraz 2) proceduralne „dialog i współpracę”. Inaczej rzecz ujmując, to dialog i współpraca stanowią podstawowe środki (sposób postępowania) w procesie realizacji idei solidarności, zaś solidarność determinuje kierunek prowadzonego dialogu. Powyższa konstatacja skutkuje potrzebą szerszego omówienia obu wyżej wskazanych wartości.

\section{Solidarność jako wartość kierunkująca dialog i współpracę partnerów społecznych}

Dla właściwego funkcjonowania dialogu i współpracy partnerów społecznych szczególne znaczenie odgrywa idea solidarności. Według 
Słownika języka polskiego ${ }^{55}$ „być solidarnym” to przede wszystkim poczuwać się do współodpowiedzialności, współdziałania i wspierania kogoś. Podobne pochodzenie ma termin pokrewny - „solidarność”. Pojęcie to wyprowadzane jest również z łacińskiego terminu in solidum, które w prawie rzymskim oznaczało odpowiedzialność jednego za wszystkich, wszystkich za jednego i wszystkich za wszystkich ${ }^{56}$.

Niejednokrotnie wskazywano, że solidarność w działaniu, oparta na wspólnocie poglądów odnośnie do celów i metod, nie musi być zjawiskiem etycznie pozytywnym, zarówno pod względem wspólnych poglądów, jak i efektu solidarnych działań ${ }^{57}$. Dlatego też solidarność, choć postrzegana w języku polskim przede wszystkim jako pozytywna cecha jednostki wobec grupy bądź innych jednostek, winna być rozpatrywana w odniesieniu do wartości etycznych. Wydaje się, że wśród tych wartości zdecydowany prym wiedzie zasada dobra wspólnego (art. 1 Konstytucji RP) oraz idea sprawiedliwości społecznej (art. 2 Konstytucji RP) ${ }^{58}$.

Powszechnie wskazuje się, że idea solidarności jest głęboko zakorzeniona w wieloletniej tradycji nauczania społecznego Kościoła katolickiego i ma swoją podstawę w filozofii społecznej solidaryzmu chrześcijańskiego ${ }^{59}$. Nurt ten ukształtował się z końcem XIX wieku.

55 Por. Słownik języka polskiego, red. W Doroszewski, www.sjp.pwn.pl/szukaj/solidarnie.html (21.08.2017).

56 Zob. J. Majka, Etyka społeczna i polityczna, Warszawa 1993, s. 53.

57 T. Grabińska, M. Zabierowski, Aksjologiczny krag solidarności. Rekonstrukcja uniwersalizmu solidarnościowego i jego uzasadnienie w nauce społecznej Jana Pawła II, Wrocław 1998, s. 8.

58 Por. m.in. wyrok Trybunału Konstytucyjnego z dnia 24.10.2005, sygn. P 13/04.

59 Por. m.in. wyrok Trybunału Konstytucyjnego z dnia 30.01.2001, sygn. K 17/00. Odwołania do "solidarności" pojawiały się również w innych koncepcjach, niekoniecznie związanych z religią chrześcijańską. Powołanie się na elementy solidarności można znaleźć m.in. u Arystotelesa, jak również u klasyków ekonomii, takich jak A. Smith, który uważał, że podział pracy w dochodowym procesie produkcji i wspólnota interesów producentów opierają się na wzajemnej zależności uczestników tego procesu. Nawiązują do niej też pozytywiści - August Comte oraz Emil Durkheim. Pojęcie solidarności pojawia się 
Jego całościowe rozumienie zostało przedstawione i naukowo uzasadnione przez Heinricha Pescha - jednego z głównych teoretyków katolicyzmu społecznego ${ }^{60}$. Przeciwstawia on swój system socjalizmowi, indywidualizmowi oraz solidaryzmowi opartemu na myśli pozytywistycznej. Jego solidaryzm nie jest syntezą tych kierunków, ale niezależnym systemem społeczno-filozoficznym i ekonomicznym opartym na arystotelesowsko-tomistycznej koncepcji człowieka i społeczeństwa ${ }^{61}$. Wprowadza on do użycia pojęcie „chrześcijańskiego porządku społecznego”, przez co rozumie pierwsze zarysy nowego ładu gospodarczego i społecznego, którego głównym celem jest zaspokojenie potrzeby sprawiedliwości społecznej oraz umożliwienie każdemu człowiekowi w miarę bezpiecznej społecznej egzystencji ${ }^{62}$. Analizując ustrój społeczny, Pesch wychodzi z moralno-organicznej budowy społeczeństwa. Jednakże - w przeciwieństwie do przedstawicieli solidaryzmu pozytywistycznego - uważa on, że społeczeństwa nie należy traktować jako żywego organizmu, którym rządzą liberalizm w miejsce prawa naturalnego i centralna władza pochodząca z procesów historycznych. Twierdzi, że elementem kształtującym i warunkującym wszystkie stosunki jest godność ludzka ${ }^{63}$. Pesch nie odrzuca bezwzględnie kapitalizmu, lecz wzywając do jego reformy, wskazuje, że przyniósł on też prawdziwy postęp.

również w pracach socjalistów francuskich, np. u P.-J. Proudhona, choć preferują oni sformułowania "zjednoczenie" lub „wspólnota interesów”. Por. m.in. A. Pieniążek, M. Stefaniuk, Socjologia prawa. Zarys wykładu, Kraków 2005, s. 6672 oraz J. Sroka, Europejskie stosunki przemysłowe w perspektywie porównawczej, Wrocław 2000, s. 46-47.

60 Por. J. Mazur, Katolicka nauka społeczna, Kraków 1992, s. 106.

61 F. Mazurek, Pescha koncepcja solidaryzmu społecznego, „Rocznik Nauk Społecznych KUL" 1977 nr 5, s. 33.

62 Por. Z. Waleszczuk, Globalizacja solidarności. Solidarność odpowiedziq na wyzwania procesów globalizacji w świetle nauczania społecznego Jana Pawła II, Wrocław 2006, s. 197.

63 Por. A. M. Hespanha, Korzenie idei solidarności we współczesnej teorii prawa (w końcu IX i na poczq̨tku XX wieku), w: Idea solidarności we współczesnej filozofii prawa i polityki, red. A. Łabno, Warszawa 2012, s. 9-22. 
Jego filozoficzne wywody ukazują solidarność jako zależność człowieka od człowieka ${ }^{64}$.

Myśl Pescha jest kontynuowana i rozwijana w doktrynie Kościoła katolickiego do dziś. Pierwszym dokumentem papieskim, w którym można znaleźć bezpośrednie odwołanie do solidarności (póki co tylko w stosunkach pracy), jest encyklika Piusa XI Quadragesimo anno, w której rozwinięta zostaje koncepcja współzależności i konieczności współdziałania pracodawców i pracowników ${ }^{65}$. Pius XI stwierdza w niej też, że pod wpływem afirmacji ideologii liberalizmu doszło do unicestwienia funkcjonowania w życiu społecznym różnego rodzaju stowarzyszeń i zrzeszeń, natomiast wszystkie obowiązki tych unicestwionych zrzeszeń przejąć musiała władza państwowa ${ }^{66}$.

Aktualne ujęcie solidarności w nauce społecznej Kościoła ma swoje początki w dokonaniach Soboru Watykańskiego II $^{67}$. Główne myśli i zadania Soboru w dziedzinie głoszenia solidarności i braterstwa przejęli też kolejni papieże $e^{68}$. Istotną rolę wśród nich odegrał Jan Paweł II, który wzbogacił naukę społeczną Kościoła o swoją wcześniejszą refleksję etyczno-filozoficzną, w której solidarność została ukazana jako postawa etyczna sytuująca się między dwoma biegunami całej społecznej doktryny Kościoła: prymatem osoby ludzkiej i troską o dobro wspólne ${ }^{69}$.

64 Z. Waleszczuk, Globalizacja solidarności..., dz. cyt., s. 216.

65 Pius XI, Encyklika Quadragesimo anno, 74, również 53, 57, 65, 73. Warto zaznaczyć, że w niemieckiej wersji encykliki użyto słowa "Solidarität”, natomiast w tłumaczeniu polskim pojawia się czasem sformułowanie „zgoda wewnętrzna”.

66 Pius XI, Encyklika Quadragesimo anno, 78.

67 Por. Sobór Watykański II, Konstytucja duszpasterska o Kościele w świecie współczesnym Gaudium et spes, 22.

68 Por. m.in. wydana przez Jana XXIII Encyklika Mater et Magistra o współczesnych przemianach społecznych w świetle nauki chrześcijańskiej $(23,92)$, w której wzywał on do solidarności w relacjach przedsiębiorca-pracownik i stanął na stanowisku, że stosunki przedstawicieli świata pracy i kapitału winny charakteryzować się wzajemną życzliwością i szacunkiem w zespalaniu wspólnie sił do pracy, rozumianej jako obowiązku służby innym.

69 K. Wojtyła, Osoba: podmiot i wspólnota, w: K. Wojtyła, Osoba i czyn i inne studia antropologiczne, red. T. Styczeń, Lublin 1994, s. 404 oraz Jan Paweł II, Encyklika Sollicitudo rei socialis, 38. 
Według katolickiej nauki społecznej solidarność jest zatem czymś najbardziej właściwym dla człowieka - istoty społecznej i otwartej. Realizowanie się człowieka pośród ludzi i z ludźmi dokonuje się bowiem na gruncie dobra wspólnego. Solidarność jest też odpowiedzią na wzrastającą obecnie współzależność między ludźmi, a także między narodami ${ }^{70}$. Należy wobec tego uznać, że idea ta koncentruje się na człowieku z jego niezbywalną godnością jako podstawowym podmiocie życia społecznego. Warto przy tym zaznaczyć, że - zgodnie z nauką społeczną Kościoła - ludzie nie są do solidarnych postaw w żaden sposób zdeterminowani. Kościół stoi raczej na stanowisku, że - jako wolne istoty społeczne - skłaniają się ku nim w sposób naturalny, a ponadto uznają tego rodzaju wybór jako najbardziej logiczny i uzasadniony. Solidarność jest więc wyborem człowieka, nie zaś instynktowną reakcją „zwierzęcia społecznego" 71 . W związku z tym, jeżeli jednostka pragnie urzeczywistniać swoje interesy, musi się liczyć również z interesami innych. To zaś zmusza ją do współpracy i współdziałania $\mathrm{z}$ innymi.

Solidarność stanowi więc naturalną konsekwencję jednoczesnego i harmonijnego współwystępowania dwóch konstytucyjnych wartości: poszanowania godności ludzkiej oraz (wynikającego z niej) obowiązku dbania o dobro wspólne. Ponadto wskazuje się, że solidarność partnerów społecznych z art. 20 Konstytucji należy również wiązać z zasadą pomocniczości ${ }^{72}$. Solidarność powinna realizować się zatem przez samopomoc jednostek, następnie na pomocy organizowanej

70 H. Skorowski, Moralność społeczna. Wybrane zagadnienia z etyki społecznej, gospodarczej i politycznej, Warszawa 1996, s. 43.

71 F. Kampka, Solidarność w nauczaniu Jana Pawła II, w: Idea solidarności dzisiaj, red. W. Zuziak, Kraków 2001 (Działanie według Wartości).

72 Por. wyrok Trybunału Konstytucyjnego z dnia 7.06.2001, sygn. K 20/00. Do zasady pomocniczości odwoływał się w tym kontekście również Pius XI w Encyklice Quadragesimo anno, 74, również 53, 57, 65, 73). 
siłami społecznymi, a dopiero w ostateczności akceptować pomoc udzielaną przez państwo, w minimalnym, niezbędnym zakresie ${ }^{73}$.

Reasumując, idea solidarności głosi wspólnotę interesów wszystkich jednostek i grup społecznych w obrębie danej społeczności, a także obowiązek partycypowania w obciążeniach na rzecz społeczeństwa. Zakłada wzajemne zrozumienie między jednostkami, grupami społecznymi i państwem. Idea solidarności nie neguje przy tym prawa do interesów własnych. Nie wyklucza także sprzeczności interesów, ale wymaga w sytuacji konfliktowej współodpowiedzialności, dialogu i porozumienia. Inaczej mówiąc, wymaga ona samoograniczenia, którego granice są ustalane przez partnerów społecznych $\mathrm{w}$ drodze dialogu $\mathrm{u}^{74}$.

\section{Dialog i współpraca partnerów społecznych jako zinstytucjonalizowana procedura kształtowania ustroju gospodarczego}

Dialog i współpraca to drugi element kształtujący społeczny aspekt funkcjonującej w Polsce gospodarki rynkowej. Treść art. 20 w omawianym zakresie wskazuje, że Konstytucja uznaje dialog i współpracę partnerów społecznych, którzy przy rozwiązywaniu zaistniałych problemów i konfliktów społecznych i ekonomicznych winni mieć na względzie solidarność społeczną skorelowaną z odwołaniem do treści art. 1 Konstytucji RP formułującego zasadę dobra wspólnego. $\mathrm{Z}$ zasady dobra wspólnego wynika bowiem dyrektywa gotowości przedłożenia - w razie konieczności - dobra ogólnego ponad dobro

73 Szerzej na temat idei solidarności por również: Idea solidaryzmu we współczesnej filozofii prawa i polityki, dz.cyt., jak również Idea solidaryzmu we współczesnym prawie konstytucyjnym. Doświadczenia polskie i międzynarodowe, red. A. Łabno, Warszawa 2015.

74 K. Strzyczkowski, Konstytucyjna zasada..., dz. cyt., s. 33. 
indywidualne czy też partykularny interes grupowy ${ }^{75}$. Spory o interesy pomiędzy partnerami społecznymi powinny być zatem rozwiązywane w drodze ustawowo określonych procedur, w których środkami ostatecznymi są - pozostające już poza zakresem pojęcia dialogu i współpracy - strajk i lokaut ${ }^{76}$.

Jak wcześniej wspomniano, dialog i współpraca partnerów społecznych stanowi swoistą metodę dochodzenia przez partnerów społecznych do solidarności i dobra wspólnego. Sformułowanie to ma zatem wymiar proceduralny $\mathrm{w}$ tym sensie, że formułuje postulat stworzenia pewnych sformalizowanych procedur $z$ udziałem państwa oraz partnerów społecznych ukierunkowanych na wspólne budowanie (współkształtowanie) ładu społeczno-gospodarczego. Ogólność konstytucyjnej formuły „dialogu i współpracy” nakłada więc na ustawodawcę obowiązek wypełnienia treścią tego normatywnego pojęcia. W literaturze zauważa się, że ustawowa regulacja powinna normować w szczególności zasady i tryb dialogu jako formy porozumiewania się partnerów społecznych i współpracy między nimi ${ }^{77}$. Jako realizację przedmiotowego postulatu wskazuje się w szczególności opartą na idei solidarystycznego korporacjonizmu koncepcję rad społeczno-gospodarczych, w których obok przedstawicieli państwa uczestniczą przedstawiciele reprezentatywnych grup interesu takich jak związki

75 Z. Witkowski, Wybrane zasady..., dz. cyt., s. 85-86.

76 T. Liszcz, Przyszła Konstytucja Rzeczypospolitej Polskiej a prawo pracy, w: Projekt Konstytucji. Wartości i prawo, red. W. Skrzydło, Lublin 1997, s. 76.

77 J. Ciapała, Partnerstwo społeczne, w: W. Skrzydło, S. Grabowska, R. Grabowski, Konstytucja Rzeczypospolitej Polskiej. Komentarz encyklopedyczny, dz. cyt., s. 342. Tak również P. Sarnecki, Ogólna charakterystyka państwowości w Konstytucji RP, w: Prawo konstytucyjne Rzeczypospolitej Polskiej, red. P. Sarnecki, wyd. 7 popr., Warszawa 2008, s. 85. Wskazać również należy, że niektórzy badacze uważają za niecelowe wprowadzanie do Konstytucji zbyt wielu zagadnień organizacyjnych dotyczących gospodarki. Dotyczy to również instytucjonalizacji korporacjonizmu w postaci izby społeczno-gospodarczej, dla której wystarczającą konstytucyjną podstawę tworzy swoboda zrzeszania się i samodzielność wszelkich ciał samorządowych. Por. K. Sobczak, Wolność gospodarcza w kręgu problemów konstytucyjnych, „Przegląd Ustawodawstwa Gospodarczego” 1996 nr 3, s. 8. 
zawodowe, organizacje pracodawców, organizacje zrzeszające rolników i inne zinstytucjonalizowane przejawy samoorganizacji społeczeństwa obywatelskiego.

Wskazać również należy, że tak rozumiana idea dialogu społecznego była realizowana praktycznie od początków polskiej transformacji ustrojowej. Co więcej, można pokusić się o stwierdzenie, że to dialog społeczny (ukierunkowany na autentyczną solidarność) uruchomił cały cykl wydarzeń, który skutkował upadkiem komunizmu w Polsce. Mowa tutaj w szczególności o działalności NZSS „Solidarność" oraz porozumieniach zawartych pod koniec sierpnia 1980 roku przez międzyzakładowe komitety strajkowe ze stroną partyjno-rządową. Co prawda porozumienia te w znacznej części dotyczyły zbiorowego prawa pracy $^{78}$, niemniej jednak wydarzenia te dały bez wątpienia początek pluralizmowi politycznemu i wolności słowa - podstawowym warunkom funkcjonowania dialogu społecznego. Kolejny znaczący przełom zapoczątkował natomiast rozpoczęty wiosną 1989 roku dialog Okrągłego Stołu prowadzony pomiędzy NSZZ „Solidarność" reprezentującą większość społeczeństwa a PZPR i organizacjami koncesjonowanymi przez tę partię. W wyniku trwających kilka miesięcy bezprecedensowych w bloku wschodnim negocjacji politycznych podpisano porozumienie, które oznaczało zasadniczą reformę ówczesnego państwa i zapowiadało wprowadzenie demokracji parlamentarnej ${ }^{79}$.

78 Na temat charakteru prawnego porozumień sierpniowych zob. w szczególności L. Garlicki, Refleksje nad charakterem Porozumienia Gdańskiego, "Państwo i Prawo" 1981 nr 1, s. 3-13 oraz M. Pliszkiewicz, Porozumienia Ogólnopolskie i ich znaczenie dla prawa pracy, „Państwo i Prawo” 1981 nr 6, s. 28-37.

79 Autorzy porozumienia Okrągłego Stołu zgodzili się też na powołanie wspólnej instytucji monitorującej realizację postanowień porozumienia, która miała być forum dialogu społecznego. Zakładano, że zasiadać w niej będą przedstawiciele rządu, NSZZ "Solidarność" oraz przedstawiciele Episkopatu. Rozwiązanie to w pewnej mierze ukierunkowane było na tworzenie ładu o cechach neokorporacyjnych, w którym rząd negocjuje z demokratycznie wyłonionymi partnerami społecznymi. Nigdy jednak nie powołano tej instytucji. Por. J. Gardawski, Dialog 
Zwieńczeniem instytucjonalizacji idei dialogu społecznego w polskiej praktyce ustrojowej było powołanie do życia w 1994 roku Trójstronnej Komisji do spraw Społecznych i Gospodarczych ${ }^{80}$. Normy dotyczące funkcjonowania tej instytucji zostały w sposób znaczący zmodyfikowane po wejściu w życie Konstytucji RP ${ }^{81}$. Zasadniczą słabością Komisji okazało się jednak zbyt duże organizacyjne i finansowe uzależnienie od strony rządowej ${ }^{82}$. Spowodowało to istotną dysfunkcję w obszarze realizacji zadań Komisji, a w konsekwencji doprowadziło do jej rozwiązania i powołania nowej instytucji - Rady Dialogu Społecznego ${ }^{83}$.

Pomimo występowania pewnych problemów w funkcjonowaniu tych instytucji idea negocjacji społecznych w ramach różnego rodzaju platform dialogu społecznego od początku była traktowana jako wartość. Komisja Trójstronna bardzo szeroko ukształtowała wizję swoich kompetencji, przy czym w praktyce nie zajmowała się sprawami wykraczającymi poza kwestie społeczno-gospodarcze. Te szeroko określone kompetencje oraz względy historyczne spowodowały, że swoją aktywnością Komisja Trójstronna (a następnie Rada Dialogu Społecznego) wkraczała w sferę działalności rządu oraz (w mniejszym

społeczny w Komisji Trójstronnej, w: Organizacje pozarzq̨dowe. Dialog obywatelski. Polityka państwa, red. M. Rymsza, Warszawa 2007, s. 237-238.

80 Por. uchwała Rady Ministrów nr 7/94 z dnia 15.02.1994 w sprawie powołania Trójstronnej Komisji do Spraw Społeczno-Gospodarczych (niepublikowana), która regulowała m.in. skład, organizację i kompetencje Komisji; następnie znowelizowana uchwałami Rady Ministrów nr 69 z dnia 18.06.1996 i nr 144 z dnia 17.12.1996, zmieniającymi uchwałę w sprawie powołania Trójstronnej Komisji do Spraw Społeczno-Gospodarczych (niepublikowana).

81 Ustawa z dnia 6.07.2001 o Trójstronnej Komisji do Spraw Społeczno- Gospodarczych i wojewódzkich komisjach dialogu społecznego (Dz. U. 2001 Nr 100 poz. 1080).

82 Historię oraz ocenę funkcjonowania Trójstronnej Komisji do Spraw Społecznych i Gospodarczych w Polsce w sposób kompleksowy omawia J. Gardawski w monografii pt. Dialog społeczny w Polsce. Teoria, historia, praktyka, Warszawa 2009.

83 Ustawa z dnia 24.07.2005 o Radzie Dialogu Społecznego i innych instytucjach dialogu społecznego (Dz. U. 2015, poz. 1240). 
stopniu) władzy ustawodawczej, a w konsekwencji stała się główną instytucją konstytucyjnego dialogu społecznego w Polsce. Za jej pomocą dokonano swoistego „wmontowania” w model gospodarki rynkowej instytucji, której celem jest przeciwdziałanie potencjalnym socjalnym napięciom i zagrożeniom $\mathrm{w}$ imię pokoju społecznego ${ }^{84}$.

\section{Podsumowanie}

Treść art. 20 Konstytucji RP w oryginalny sposób formułuje podstawy ustroju gospodarczego Polski. Dotyczy to w szczególności wskazania, że jednym z filarów (panującej w Polsce) społecznej gospodarki rynkowej jest „solidarność, dialog i współpraca partnerów społecznych”. Przepis ten stwarza prawną podstawę do tworzenia korporatystycznych instytucji dialogu partnerów społecznych. Funkcjonowanie tych instytucji pozwala grupom interesu (partnerom społecznym) wpływać na procesy decyzyjne oraz treść stanowionego prawa w sprawach społeczno-gospodarczych, a w konsekwencji prowadzić do zachowania pokoju społecznego. Osiągnięcie tego stanu jest w dużej mierze zadaniem mediatora, którym powinna być administracja publiczna ${ }^{85}$.

Funkcjonowanie tego rodzaju norm konstytucyjnych należy bez wątpienia uznać za rozwiązanie oryginalne, które niebagatelnie wpływa na sposób interpretacji przepisów Konstytucji, w szczególności w zakresie kształtowania ustroju gospodarczego. Regulacja ta jest ponadto przejawem proceduralizacji prawa, polegającej na tworzeniu odpowiednich mechanizmów komunikacji między różnymi

84 C. Banasiński, Konstytucyjne podstawy ustroju gospodarczego, w: H. Prawo administracyjne. Zagadnienia administracyjnoprawne, red. H. Gronkiewicz-Waltz, M. Wierzbowski, Warszawa 2009, s. 43.

85 K. W. Frieske, L. Machol-Zajda, Instytucjonalne ramy dialogu społecznego w Polsce: szanse i ograniczenia, w: Dialog społeczny. Zasady, procedury i instytucje w odniesieniu do podstawowych kwestii społecznych, red. K. W. Frieske i in., Warszawa 1999, s. 13. 
podsystemami, mimo odmienności ujawnianych preferencji, koniecznych w sytuacji, kiedy prawo nie ma szans na zespolenie wszystkich rozbieżnych interesów i wartości w jeden spójny system. Wówczas to następuje przesunięcie ciężaru regulacji prawnej z norm prawno-materialnych na normy proceduralne określające sposób osiągania pożądanych stanów rzeczy ${ }^{86}$.

Podejście takie powoduje zmianę wielu koncepcji teoretycznoprawnych, w tym także poglądów dotyczących tworzenia prawa ${ }^{87}$. Istotną rolę odgrywa tutaj teoria prawa responsywnego, która opiera się na negocjacyjnej formie tworzenia prawa, gdzie władza staje się partnerem i uczestnikiem negocjacji. W efekcie stanowione prawo jest w znaczącej mierze wynikiem konsensusu, nieformalnej ugody, a także szeroko pojętych umów, które są uznanymi w systemie sposobami tworzenia norm postępowania. Ponadto w tym negocjacyjnym systemie prawa udzielanie i delegowanie kompetencji obejmuje podmioty spoza aparatu państwowego - zrzeszenia, korporacje czy też związki zawodowe - a co za tym idzie, powiązania występujące w tym systemie nie mają charakteru hierarchicznego. Kluczowa w tym modelu jest zmiana sposobu działania władzy politycznej, która z podmiotu zmierzającego do podporządkowania sobie działania innych podmiotów społecznych staje się partnerem do dyskusji. W ten sposób pionowe (hierarchiczne) zarządzanie zostaje w dużej części zastąpione poziomym (partnerskim) koordynowaniem procesów decyzyjnych w ramach struktury, w której uczestniczy wiele zainteresowanych podmiotów. Dzięki temu odpowiedzialność za rozwiązanie niektórych problemów dotychczas spoczywających na państwie zostaje - w pewnym stopniu - przejęta przez podmioty społeczne, głównie związki zawodowe i związki pracodawców. Mówi się w tym kontekście wręcz o ewolucyjnej drodze tworzenia prawa:

86 K. Strzyczkowski, Konstytucyjna zasada..., dz. cyt., s. 33-34.

87 E. Kustra, Polityczne problemy tworzenia prawa, Toruń 1994, s. 33nn. 
od koncepcji prawa jako techniki i rozkazu do koncepcji prawa jako rozmowy, w której istotną rolę odgrywa zespół procedur negocjacyjnych i dialogu ${ }^{88}$. Ewolucja ta skutkuje również zmianą sposobu funkcjonowania państwa, które działa na zasadzie współtworzenia sieci i mechanizmów koordynacji działań zbiorowych ${ }^{89}$. W konsekwencji zdecydowanie zanika tradycyjny, weberowski model działania państwa. Zastępują go mniej lub bardziej rozczłonkowane układy sieciowe, w których obrębie państwo może sprawować nadzór i kontrolę $^{90}$. Tak rozumiane teorie sieciowe łączone są z pojęciem rządzenia wielopasmowego (ang. multi-level governance) ${ }^{91}$.

Zaznaczyć należy również, że na gruncie obowiązujących norm ustrojowych dialog społeczny nie jest wyłącznie instrumentem współkształtowania ustroju gospodarczego Polski. W tym kontekście niebagatelna znaczenie ma treść - znajdującego się w preambule do Konstytucji RP - odwołania do dialogu społecznego jako narzędzia reprezentacji i artykulacji interesów (potrzeb) społeczeństwa obywatelskiego w procesach decyzyjnych podejmowanych przez organy władzy publicznej w sferze szeroko rozumianych spraw publicznych ${ }^{92}$. Dialog społeczny w tym ujęciu staje się zatem procesem konsultowania rozmaitych, kluczowych decyzji w sprawach publicznych z zainteresowanymi stronami, po to, aby wychodząc poza strukturę instytucji politycznych, „uspołecznić” mechanizmy podejmowania decyzji

88 L. Morawski, Główne problemy współczesnej filozofii prawa. Prawo w toku przemian, Warszawa 2005, s. 165.

89 J. Hausner, M. Marody, Polski talk show: dialog społeczny a integracja europejska, Kraków 2001, s. 118-120 (EU-monitoring, 5).

90 Więcej na ten temat por. m.in. J. Sroka, Dialog społeczny w wojewódzkich komisjach dialogu społecznego na przykładzie dolnośląskiej WKDS, w: Organizacje pozarządowe. Dialog obywatelski. Polityka państwa, dz. cyt., s. 218-219.

91 Por. m.in. H. Izdebski, Fundamenty współczesnych państw, Warszawa 2007, s. 189-190.

92 Za: J. Jendrośka, Obowiq̨zek konsultowania organizacji pozarządowych a nowa Konstytucja Rzeczypospolitej Polskiej, w: Podstawy prawne funkcjonowania organizacji pozarzqdowych, red. M. Wyrzykowski, Warszawa 1999, s. 75. 
przez wprowadzenie do procesów decyzyjnych wyspecjalizowanych informacji i wiedzy oraz uwzględnienie specyficznych interesów grupowych, w szczególności tych, które nie są reprezentowane w strukturze instytucji wyłącznie politycznych. Tendencja ta wyraża się właśnie powoływaniem różnego rodzaju organów pośredniczących pomiędzy społeczeństwem a rządem i parlamentem, co pozwala tym organom wpływać na procesy decyzyjne, jak również racjonalizować dotychczasowy system reprezentacji politycznej przez uzupełnienie go reprezentacją funkcjonalną (zawodowo-społeczną) ${ }^{93}$. Zważywszy na treść wyżej powołanych regulacji konstytucyjnych, wydaje się, że tak rozumiany szeroki, zinstytucjonalizowany dialog społeczny powinien z czasem stawać się coraz bardziej powszechnym instrumentem kształtowania stosunków politycznych i społecznych.

93 K. Działocha, J. Trzciński, K. Wójtowicz, Studia nad udziałem grup interesów w procesie tworzenia prawa, Wrocław 1987, s. 185. 
- 